を行うとともに，ユーザーの利便性，事業性，社会受容性など を検証し，普及開始の課題を解決することが目的である．政府 は FCV や水素供給インフラ商用化，海外輸出などにより，6 兆円規模の市場創出効果を見込んでおり，2025 年の $\mathrm{CO}_{2}$ 削減 効果が年間 400 万トンに達すると試算している。

福島第一原子力発電所の事故を踏まえて, 再生可能エネル ギー等の $\mathrm{CO}_{2}$ フリーエネルギーシステムへのニーズが高まっ た.この中で, $\mathrm{CO}_{2}$ フリ一水素の大規模導入も注目を集め始め た. 海外に豊富に存在する風力や太陽光などの再生可能エネル ギー由来の電力を用いて水素を製造し，わが国に輸送するなど の構想の検討が行われた．また中間シナリオとして，海外の化 石燃料を原料として水素を製造し，炭酸ガスを現地で隔離貯蔵 したのち水素をわが国に輸送・供給するなどの，エネルギー供 給・利用全体で $\mathrm{CO}_{2}$ を排出しない仕組みも検討された。国内 の再生可能エネルギーを電力用途に利用する際の出力変動を, 二次電池で平滑化するなどの検討が盛んに行われているが，二 次電池とともに水素を利用するシステムに関する研究も活発化 している

[坂田 與 (財) エネルギー総合工学研究所]

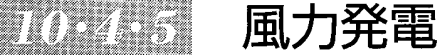

世界全体の風力発電累積導入量は GWEC (Global Wind Energy Council) の統計によると 2011 年末で 2 億 3767 万 $\mathrm{kW}$ に達したが，これは前年比 $20 \%$ の増加である．2011 年の世界 の新規導入量は 4056 万 $\mathrm{kW}$ で，中国が 1763 万 $\mathrm{kW，アメリ}$ カが 682 万 $\mathrm{kW}$ となり中国の一番の状況は変わらない. ヨー ロッパ全体では 1028 万 kW で中国の急速な伸びに二番手に なっているが順調に増加していることがわかる，総設備容量で も中国では近年の急速な増加の結果から 6236 万 $\mathrm{kW}$ に達し， アメリカの 4692 万 $\mathrm{kW}$ ，ドイッの 2906 万 $\mathrm{kW}$ が続く. 各大

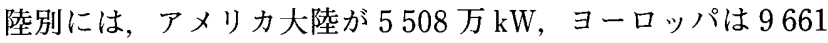
万 $\mathrm{kW} ，$ アジアが 8203 万 $\mathrm{kW}$ ，オセアニアとその他で 395 万 $\mathrm{kW}$ となった。わが国は，アジアでは中国，インドに続く三番 手であり，2011 年末現在で累積導入量は GWECの統計では 250.1 万 $\mathrm{kW}$ である。 また，2011 年 3 月の東日本大震災と福 島原発事故以降に国内エネルギーの今後について多くの議論が 行われているが，風力を含む再生エネルギーの導入検討が広範 囲の方面で始まった。また国内の法整備も進み再生可能エネル ギー固定買い取り価格と全量買い取り法が決まりこの 7 月から は大型の風力発電設備においては 23.1 円 $/ \mathrm{kWh}$ での買い取り が始まった。このために昨年度は価格が決まらないことからモ ラトリアム状況であった新規の風車建設も今後増えていくもの と考えられる. 陸上の風力発電設備設置に加えて, 総発電量を 増加させるために洋上風車の実質的な研究や㭘討が広く進んで きた．NEDO（新エネルギー・産業技術総合開発機構）が中心 になって着底式の洋上風車に関する研究と実施試験が銚子沖と 北九州の 2 海域で進んでいる。 また環境省では五島沖において 浮体式の洋上風車の研究が進行している. 欧米に扔いても洋上 風車の開発が急速に進んでいる状況であるし，また中国や韓国 も洋上風車の開発に積極的に取り組んでいる状況である. 一方 経済産業省は震災復興の支援と最新の技術開発のためにいわき 沖に浮体式洋上風車の建設を考えており，これらの技術開発を 進めることで世界第 6 位の海域を持つ日本の洋上における風力 発電の進歩に繋がることを期待したい。

風車に関する研究では NEDO 等を中心に，風車が対面する
課題克服の諸技術や，新規適用に関する開発等での研究が引き 続き行われている．洋上発電設置に関する環境影響評価に向け ての取り組みも併せて行われている。新世代風車の研究では大 型化研究が $7 \mathrm{MW}$ 超大型風力発電システム技術研究や事業性に 関する研究開発が進んでいることに加え, 経済産業省の浮体式 洋上ウインドファーム実証試験事業が開始された．風力発電装 置では日本の乱流や台風といった風に関する研究や落雷の計測 調査等は引き続き行われているが，加えてわが国の電力系統を 分散エネルギーに適したシステムとするための系統に関する研 究が広く始められている。その他寒冷地対策・騒音・高山等へ の特殊仕様, 電力品質 (二次電池併設システム・気象予測連動 等)・エネルギー輸送などの課題を克服し環境問題, エネルギー 問題，経済問題を解決し，持続可能な社会構築に向けて継続的 で活発な技術開発が今後も必要で，日本のエネルギーを支える ための基幹産業となることが期待される。

〔勝呂 幸男 一般社団法人 風力エネルギー学会〕

\section{0-4 涪 地熱発電}

国際地熱協会 (GIA) によると，2009 年の世界の地熱発電 設備容量は 1070 万 $\mathrm{kW}$ で, 2000 年と比較し 3 割以上増加し ており，海外での地熱発電は活発に推進されている.

一方，国内の地熱発電所は，1999 年に八丈島地熱発電所が 運転開始して以降，新たなものは建設されておらず，2012 年 3 月時点の認可出力合計は 54.0 万 $\mathrm{kW}$ となっている. このよ うな中で, (独) 新エネルギー・産業技術総合開発機構 (NEDO) が先導的な地熱開発の促進調査を実施した山葵沢・秋ノ宮地域 （秋田県湯沢市）では，民間企業による地熱発電所の建設計画 が策定され，建設に向けた環境影響評価（アセスメント）の手 続きに入っている. 発電出力は $42000 \mathrm{~kW}$ 級を予定して打り, 2015 年に着工，2020 年に運転を開始する計画であり，1999 年以来の地熱発電所の事業化が進められている.

また，再生可能エネルギーの固定買取価格（地熱においては 1.5 万 $\mathrm{kW}$ 以上で 27.3 円 $/ \mathrm{kWh} ， 1.5$ 万 $\mathrm{kW}$ 未満で 42 円 $/ \mathrm{kWh})$ が決まり，2012 年 7 月から再生可能エネルギーの導入拡大を 目的とした固定価格買収制度が始まったことから，今後の地熱 開発に大きな弾みがつくと期待している.

〔田中 清隆 (独) 新エネルギー・産業技術総合開発機構〕

\section{Hod-y 電力貯蔵}

東日本大震災以降の電力供給力の低下に伴って, 電池電力貯 蔵技術への期待が高まっている。しかし，定置用蓄電システム として，実績を重ねてきた（世界 6 力国に合計 174 力所， $305 \mathrm{MW}$ 総計） NAS 電池へ急速な普及拡大が望まれたが，火 災事故により製造中止の事態となっている (3 月時点)。一方， 従来から進渉が図られてきた国プロジェクト「次世代エネル ギー・社会システム実証事業」等では，定置用蓄電システムの ほか，電気自動車と家庭電力を連系する，いわゆる V2H など が進められている，さらに，1kWh 級のリチウムイオン電池シ ステムが家電量販店から販売されるなど，社会的な導入の動き が加速した. これに対応して，消防庁規制の見直し，日本電池 工業会規格（SBA S1101-2011）制定などが進んだ.なお， 2012 年度からは定置用りチウムイオン蓄電池システムの家 庭・事業者での導入を支援し，需要家サイドでのピークカッ 卜・停電対策を図る補助事業が始まる.

〔寺田 信之一般財団法人 電力中央研究所〕 